\title{
Potential use of heather to control gastrointestinal nematodes in goats ${ }^{\text {is }}$
}

\author{
J. Moreno-Gonzalo a , I. Ferre ${ }^{a}, *$, R. Celaya ${ }^{b}$, P. Frutos ${ }^{c}$, L.M.M. Ferreira ${ }^{d}$, G. Hervás ${ }^{c}$, \\ U. García ${ }^{b}$, L.M. Ortega-Mora ${ }^{a}$, K. Osoro $^{b}$ \\ a Grupo SALUVET, Departamento de Sanidad Animal, Facultad de Veterinaria, Universidad Complutense de Madrid, Ciudad Universitaria s/n, 28040 Madrid, \\ Spain \\ b Servicio Regional de Investigación y Desarrollo Agroalimentario (SERIDA), Área de Sistemas de Producción Animal, Consejería de Medio Rural y Pesca, \\ Principado de Asturias, 33300 Villaviciosa, Spain \\ c Instituto de Ganadería de Montaña, CSIC-ULE, Finca Marzanas, 24346 Grulleros (León), Spain \\ d CECAV, Departamento de Zootecnia, Universidade de Trás-os-Montes e Alto Douro, PO Box 1013, 5000-911 Vila Real, Portugal
}

\section{A R T I C L E I N F O}

Article history:

Available online 17 November 2011

\section{Keywords:}

Goat

Ericaceae

Tannin

Gastrointestinal nematode

Anthelmintic control

Animal performance

\begin{abstract}
A B S T R A C T
In the last decade, numerous studies have been carried out to evaluate the potential anthelmintic benefit of the consumption of bioactive plants in small ruminants, in order to reduce the dependence on conventional chemotherapy and supporting a sustainable control of gastrointestinal (GI) parasitism. This review summarizes the anthelmintic and nutritional effects of heather (shrub species belonging to the Ericaceae family, such as Erica spp. or Calluna vulgaris) supplementation in grazing goats naturally infected by GI nematodes. The experiments were carried out in a mountain area in north-western Spain where shrubby heather-gorse vegetation is dominant. Some plots were established, in which the vegetation had been improved by soil ploughed and dressing and sowing perennial ryegrass (Lolium perenne) and white clover (Trifolium repens), and removing any heather that was present. Cashmere goats reared outdoors under pasture conditions were used in the experiments. The trials compared the response to GI nematode infections, animal performance and nutrition in goats supplemented or not with heather. Interactions between heather availability and other alternative methods to control GI nematode infections based on grazing management (stocking rate) or nutrition (energy supply) as well as the potential adaptation of the rumen microbiota to the consumption of tannins, were also studied. The results suggest that (i) heather supplementation in grazing goats significantly reduces the level of GI nematode egg excretion, (ii) the faecal nematode egg count reduction could be associated with a decrease in worm fertility and/or reduction in the establishment of incoming third-stage larvae, (iii) consumption of heather is associated with an apparent greater resilience of goats to GI nematode infections, and (iv) the amount of tannins consumed by the goats supplemented with heather does not seem to be associated to anti-nutritional effects which eventually resulted in a better animal performance in the animals incorporating these shrubs in their diet. Practical application of this knowledge in temperate areas would support the management of plots integrating improved pastures with high nutritive value (ryegrass-white clover) with natural vegetation communities.
\end{abstract}

(c) 2011 Elsevier B.V. All rights reserved.

\footnotetext{
is This paper is part of the special issue entitled 'Specificities of parasitism in goats and sheep: interactions with nutrition and control strategies', Guest Edited by Pilar Frutos, Hervé Hoste, Smaragda Sotiraki and Martin Hall.

* Corresponding author. Tel.: +34 913944094; fax: +34 913943908.

E-mail address: iferrepe@vet.ucm.es (I. Ferre).
} 


\section{Promising use of plants as nutraceuticals in goats}

Grazing small ruminants are commonly parasitized by gastrointestinal (GI) trichostrongyle nematodes (suborder Trichostrongylina) worldwide. In goats at pasture, GI nematodes infection reduces the efficiency of production by decreasing voluntary feed intake, live weight gain, milk yield, and carcass quality. In addition, they have a detrimental effect on the general welfare of the infected animals (Coop and Kyriazakis, 2001; Hoste et al., 2005b). To control these parasitic infections, the repeated administration of broad-spectrum anthelmintic drugs integrated, where practical, with grazing and management strategies, is the conventional method. However, the intensive chemoprophylaxis with anthelmintic drugs has led to a widespread development of anthelmintic-resistant populations of parasitic nematodes, particularly in sheep and goats, in both northern and southern hemispheres (Kaplan, 2004). Furthermore, there is an increasing public concern over drug residues in meat and milk products, and a potential risk for environmental contamination (Waller and Thamsborg, 2004). Anthelmintics may be also unavailable in developing countries due to their high cost. For these reasons, nonchemical strategies for the control of GI nematode parasites are being investigated (Ketzis et al., 2006; Stear et al., 2007). In small ruminants, alternative approaches for control of GI nematode infections include grazing management, biological control using nematode-destroying fungi, nutritional supplementation, development of vaccines, utilization of genetic resistance, and feeding or grazing plants containing bioactive compounds. For a rationale use of these novel approaches, Stear et al. (2007) suggest that no method could be recommended excluding all others, and that the combination of methods would be the optimal strategy.

Host nutrition can directly affect GI nematodes through the ingestion of plant compounds or nutrients that may penalize parasite fitness or alter the gut (nutritional) environment in which the parasites reside (Hoste et al., 2005b, 2008). Recent in vivo and in vitro studies, showed that bioactive plants containing secondary metabolites, such as tannins, sesquiterpene lactones and flavonol glycosides, are a promising option for use in integrated nematode control in farm production systems (Brunet et al., 2008a,b; Hoste et al., 2006; Terrill et al., 2007, 2009). These plants with anthelmintic properties, known as nutraceuticals, are considered for their beneficial effects on health rather than for their direct nutritional value. The supplementation with bioactive plants in goats can enhance their ability to regulate the biology of parasite worm population (resistance) as well as their ability to withstand the negative pathophysiological effects of nematode infections (resilience) (Hoste et al., 2005b).

Condensed tannins (CT) or proanthocyanidins, polymers of flavonoid units (flavan-3-ols, flavan-3,4 diol), have been associated to ruminant nutrition benefits by increasing post-ruminal protein availability and thus reducing the consequences of GI nematode parasitism (Waghorn, 2008). Most studies on the anthelmintic properties of CT, either in experimentally or naturally infected sheep, show a reduction in nematode burdens, worm female fecundity and faecal egg count (FEC) when a moderate concentration of
CT are consumed and could, therefore, contribute to modulate the epidemiology of these parasitic diseases (Hoste et al., 2006). Recently, the number of reports showing the anthelmintic effect of $\mathrm{CT}$ rich plants on goats, naturally and experimentally infected by GI nematodes, has increased. As previously described for sheep, a reduction in egg excretion and in fecundity of the female worms have been reported in goats fed bioactive plants such as sainfoin (Onobrychis viciifolia, Hoste et al., 2005a; Paolini et al., 2003b, 2005b), sericea lespedeza (Lespedeza cuneata, Min et al., 2004, 2005; Moore et al., 2008; Shaik et al., 2006; Terrill et al., 2007, 2009), sulla (Hedysarum coronarium, Pomroy and Adlington, 2006), and Viscum verrocosum (Madibela and Jansen, 2003). These results were obtained in trials where goats were naturally or experimentally infected by GI nematodes, but under controlled conditions. However, data from grazing goats fed on tanniferous plants and naturally infected with a mixed GI nematode burden are scarce in the literature (Kabasa et al., 2000; Min et al., 2004, 2005; Moore et al., 2008). The feeding behavioural differences between sheep (mainly grazer) and goats (mainly browser), and various physiological and metabolic adaptations of goat favouring the consumption of nutritional sources rich in potentially toxic metabolites, such as $\mathrm{CT}$, indicate that goats are better adapted to exploit secondary compounds rich range vegetation (Cheeke and Palo, 1995; Hoste et al., 2005b). Furthermore, the efficacy required for novel control methods, such as CT, not only should be shown in controlled laboratory studies, but also a confirmation in farm-based trials showing a reliable economic benefit is needed (Ketzis et al., 2006).

\section{Studies on heather supplementation in grazing goats}

Heather-gorse communities are frequent in the botanical composition of natural vegetation in mountain communities of humid temperate areas such as northern Spain. Heather includes shrub species belonging to the Ericaceae family, such as Erica spp. or Calluna vulgaris, with a relatively high content of CT but low nutritive quality (Frutos et al., 2002). Goats are able to include high proportions of heather in their diets, browsing on heathlands even with high pasture availability (Celaya et al., 2007). Osoro et al. (2007b) showed the limitation of these shrub species located in marginal lands with poor soils to develop sustainable ruminant production systems. However, the availability of these shrub species, together with areas of improved grass-legume pastures, could be an effective tool to achieve the sustainability of ruminant production systems and animal welfare in these marginal mountain areas (Celaya et al., 2008).

Recently, a number of studies have been conducted to investigate the anthelmintic and nutritional effect of heather supplementation in naturally infected grazing goats by GI nematodes (Table 1). Although Bahuaud et al. (2006) studied the effect of tannin extracts from Erica erigena on the exsheatment of third-stage infective larvae of Haemonchus contortus and Trichostrongylus colubriformis, to our knowledge, the anthelmintic activity of heather in goats was not addressed by other research teams. 
Table 1

Summary of the results of experiments with tannin-containing heather (Ericaceae) supplementation in grazing Cashmere goats.

\begin{tabular}{|c|c|c|c|c|c|c|}
\hline Reference & Osoro et al. (2007a) & Osoro et al. (2007c) & Frutos et al. (2008) & Osoro et al. (2009) & Celaya et al. (2010) & \\
\hline \multicolumn{7}{|l|}{ Methods } \\
\hline Goats & $\begin{array}{l}\text { Adult non-lactating } \\
\text { (including local Celtiberic) } \\
\text { Young (<1 year-old) } \\
\text { females }\end{array}$ & Adult non-lactating & Adult lactating & Adult non-lactating & $\begin{array}{l}\text { Period } 1 \\
\text { Adult lactating }\end{array}$ & $\begin{array}{l}\text { Period } 2 \\
\text { Adult non-lactating }\end{array}$ \\
\hline$n$ & 48 & 40 & 48 & 62 & 48 & 40 \\
\hline Experimental period & June-November & May-September & May-September & May-October & April-August & August-November \\
\hline Experimental design & $\mathrm{H}+$ vs. $\mathrm{H}-$ & $\begin{array}{l}4 \text { treatments in a } 2 \times 2 \\
\text { factorial design: } \\
\mathrm{H}+\text { and } \mathrm{H}_{-} \\
\mathrm{AT}+\text { and } \mathrm{AT}-\end{array}$ & $\mathrm{H}+$ vs. $\mathrm{H}-$ & $\begin{array}{l}4 \text { treatments in a } 2 \times 2 \\
\text { factorial design: } \\
\mathrm{H}+\text { and H- } \\
\text { HSR and LSR }\end{array}$ & $\mathrm{H}+$ vs. $\mathrm{H}-$ & $\begin{array}{l}4 \text { treatments in a } 2 \times 2 \\
\text { factorial design: } \\
\mathrm{H}+\text { and } \mathrm{H}_{-} \\
\mathrm{O}+\text { and } \mathrm{O}-\end{array}$ \\
\hline Heather in the diet (\%) & ND & $\begin{array}{l}\text { 2-4 (June) } \\
20-30 \text { (September) }\end{array}$ & 29 (August) & 20 (August) & 21 (June) & 32 (October) \\
\hline $\begin{array}{l}\text { Tannin content in } \\
\text { heather (g tannic acid } \\
\text { equiv./kg DM) }\end{array}$ & $30-47$ & $70-86$ & 64 & $61-97$ & 84 & \\
\hline \multicolumn{7}{|l|}{ Results } \\
\hline FEC (\% reduction) & $\begin{array}{l}\text { Lower in } \mathrm{H}+\text { in August and } \\
\text { September in adult goats } \\
(40 \%)\end{array}$ & $\begin{array}{l}\text { Interaction between } \mathrm{H}^{+} \\
\text {and } \mathrm{AH}+(\text { September }) \\
(70-80 \%)\end{array}$ & $\begin{array}{l}\text { Lower in } \mathrm{H}+\text { in August and } \\
\text { September }(30 \%)\end{array}$ & $\begin{array}{l}\text { Interaction between } \mathrm{H}^{+} \\
\text {and SR ( } 15-30 \% \text { in HSR) }\end{array}$ & $\begin{array}{l}\text { Lower in } \mathrm{H}+\text { in July and } \\
\text { August (50\%) }\end{array}$ & $\begin{array}{l}\text { Lower in } \mathrm{H}+.(42 \%) \\
\text { Lower in } \mathrm{O}+(59 \%)\end{array}$ \\
\hline Worm burden & ND & ND & ND & $\begin{array}{l}\text { Lower } T \text {. circumcincta } \\
\text { counts in HSR } \\
\text { Trichostrongylus spp. } \\
\text { counts higher in HSR } \\
\text { Lower development and } \\
\text { fecundity in } \\
\text { Trichostrongylus spp. in } \\
\text { HSR }\end{array}$ & ND & ND \\
\hline Body weight changes & $\begin{array}{l}\text { Lower decrease in adult } \mathrm{H}^{+} \\
\text {goats }\end{array}$ & No effect & $\begin{array}{l}\text { Lower decrease in adult } \mathrm{H}^{+} \\
\text {goats }\end{array}$ & Better changes in $\mathrm{H}^{+}$ & Lower decrease in $\mathrm{H}^{+}$ & $\begin{array}{l}\text { Higher increase in } \mathrm{H}+\text { and } \\
\mathrm{O}+\end{array}$ \\
\hline Body condition score & $\mathrm{ND}$ & No effect & $\begin{array}{l}\text { Lower decrease in adult } \mathrm{H}^{+} \\
\text {goats }\end{array}$ & No effect & Lower decrease in $\mathrm{H}^{+}$ & Higher increase in $\mathrm{O}^{+}$ \\
\hline $\begin{array}{l}\text { Ruminal fermentation } \\
\text { parameters } \\
\text { Mortality }\end{array}$ & ND & $\begin{array}{l}\text { A: Lower in } \mathrm{H}^{+} \\
\text {VFA: Higher in } \mathrm{H}^{+}\end{array}$ & $\begin{array}{l}\text { A: Lower in } \mathrm{H}^{+} \mathrm{VFA} \text { : Higher } \\
\text { in } \mathrm{H}^{+} \\
7 \text { goats in } \mathrm{H}- \\
\text { Lower mortality rate in } \mathrm{H}^{+}\end{array}$ & ND & A lower in $\mathrm{H}^{+}$ & A lower in $\mathrm{H}^{+}$and $\mathrm{O}^{+}$ \\
\hline
\end{tabular}

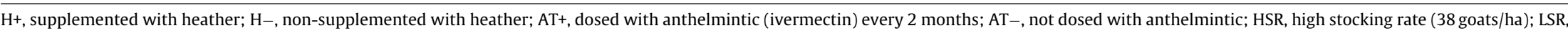

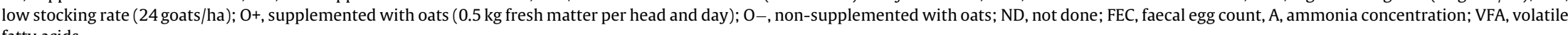
fatty acids. 
Therefore, this review focuses basically on our findings. These studies were carried out under farm conditions in a less favoured area, where grazing animals are extensively raised and included in the dynamics of a natural ecosystem. The trials compared the response to GI nematode infections and animal performance and nutrition in goats supplemented or not with heather. Interactions between heather availability and other alternative methods to control GI nematode infections based on grazing management (stocking rate) or nutrition (energy supply), as well as the potential adaptation of the rumen microbiota to the consumption of tannins, were also studied.

The experiments were conducted at "El Carbayal" research farm located in north-western Spain (lat. $43^{\circ} 21^{\prime} \mathrm{N}$, long. 6 53’W; Sierra de San Isidro, Illano, Asturias). This is a mountain area of $900-1000 \mathrm{~m}$ above sea level, with an average rainfall of $1550 \mathrm{~mm} / \mathrm{year}$, and where shrubby heather-gorse vegetation is dominant. Trials were established during the common grazing season in that area, which usually extended from late spring (May-June) to fall (October-November) depending on the climatic conditions. The studies were carried out between 2003 and 2007 on plots in which the vegetation had been improved in 2001 by ploughing the soil, dressing and sowing perennial ryegrass (Lolium perenne) and white clover (Trifolium repens), and removing any heather that was present.

Cashmere goats of different ages (does and kids) and physiological status (lactating and non-lactating) were used in the studies. The effect of heather administration to local Celtiberic non-lactating does was also investigated (Osoro et al., 2007a). All animals were reared outdoors under pasture conditions throughout the entire experimental period, without night confinement, and not excluding GI nematode infection. Before beginning the experiments, all goats were dosed orally with ivermectin $\left(0.2 \mathrm{mg}\right.$ ivermectin $/ \mathrm{kg}$ live weight, Oramec ${ }^{\circledR}$, Merial), checking the efficacy of the anthelmintic treatment 3 weeks after administration by means of individual examination of FEC and inspection of clinical signs to confirm that goats did not show patent infection.

Measurements included grass availability, botanical and chemical composition of pasture and heather, percentage of heather in the diet of each individual goat, ruminal fermentation parameters, body weight, body condition score, and parasitological studies (methods are described by Osoro et al., 2007c). Individual FECs and identification of infective third-stage larvae obtained by coprocultures were estimated in all animals at monthly or fortnightly intervals. In some experiments (Osoro et al., 2009), groups of goats of each treatment were slaughtered and adult worms were recovered from abomasums and intestines and counted in $10 \%$ aliquot samples. In order to assess the nematode development and fertility per female worm, the lengths of worms of each species were measured and the number of eggs in utero was directly counted, respectively. All experiments were carried out in accordance with Spanish Royal Decree 1201/2005 (based on European Council Directive $86 / 609 / E C C$ ) for the protection of animals used for experimental and other scientific purposes.

Supplemented goats were offered freshly cut heather ad libitum twice per week in the morning during the grazing season. The heather was offered to animals in a cage in the field, and contained mainly C. vulgaris, Erica umbellata and Erica cinerea. Erica tetralix and Daboecia cantabrica were also present but in a lower $(<5 \%)$ percentage. The proportion of heather species in the supplement did not change significantly during the experimental periods. The nutritive quality of heather was lower than that of rye-grass-clover pasture (crude protein contents ranged from 55 to $71 \mathrm{~g} / \mathrm{kg}$ DM in heather and from 78 to $209 \mathrm{~g} / \mathrm{kg}$ DM in pasture), but no great differences were found over the grazing season despite a tendency to decrease as the season advanced. Total tannin contents in heather did not vary greatly during the grazing season and the mean content analysed by the Folin-Ciocalteu assay in combination with polyvinyl-polypyrrolidone (Makkar, 2003) and expressed as g tannic acid equivalents per $\mathrm{kg}$ dry matter (g TA equiv./kg DM), ranged between 64 and $84 \mathrm{~g} / \mathrm{kg}$ DM most of the years. The mean percentage of heather incorporated into the diet of the supplemented goats varied between $20 \%$ and $32 \%$ (Table 1 ).

\section{Effects of heather supplementation on parasitic nematodes}

In the experimental conditions indicated above, the effects of heather supplementation were investigated on an established population of adult GI nematodes and indirectly on incoming third-stage larvae in goats at pasture. The presence of nematode eggs in faeces increased in all goats over the grazing season (May-June to October/November) and the greatest FECs were observed between September and November. Goats without heather supplement showed mean FECs of 5000 to 8000 eggs per gram of faeces (epg) with maximum numbers of 20,500 epg in mid-September (Osoro et al., 2007c). Nematode genera, identified on third-stage larvae obtained from coprocultures were Teladorsagia circumcincta, H. contortus, Trichostrongylus spp., Oesophagostomum spp., and Chabertia ovina. Trichostrongylus spp. were the GI nematodes more frequently identified over the whole experimental period and their percentages increased during the grazing period (from $20-30 \%$ in June to $70-90 \%$ in November). On the contrary, the percentages of $T$. circumcincta decreased from $50-70 \%$ in June to $5-10 \%$ in November. H. contortus, Oesophagostomum spp. and Ch. ovina were only detected, at low levels (less than 5\%), after midsummer.

Adult goats supplemented with heather showed lower FEC than non-supplemented animals (Fig. 1), and this effect was statistically significant between late August and the end of grazing season (Celaya et al., 2010; Frutos et al., 2008; Osoro et al., 2007a). Furthermore, a negative correlation between the percentage of heather in the diet and FEC in August and September was also found (Osoro et al., 2007c). The FEC reduction level in heather supplemented goats compared to control goats varied between $40 \%$ and $75 \%$. No differences among nematode genera identified in coprocultures due to supplementation with heather were found.

The reduction in nematode egg excretion observed in goats supplemented with heather agrees with other studies involving supplementation of CT-containing plants to 

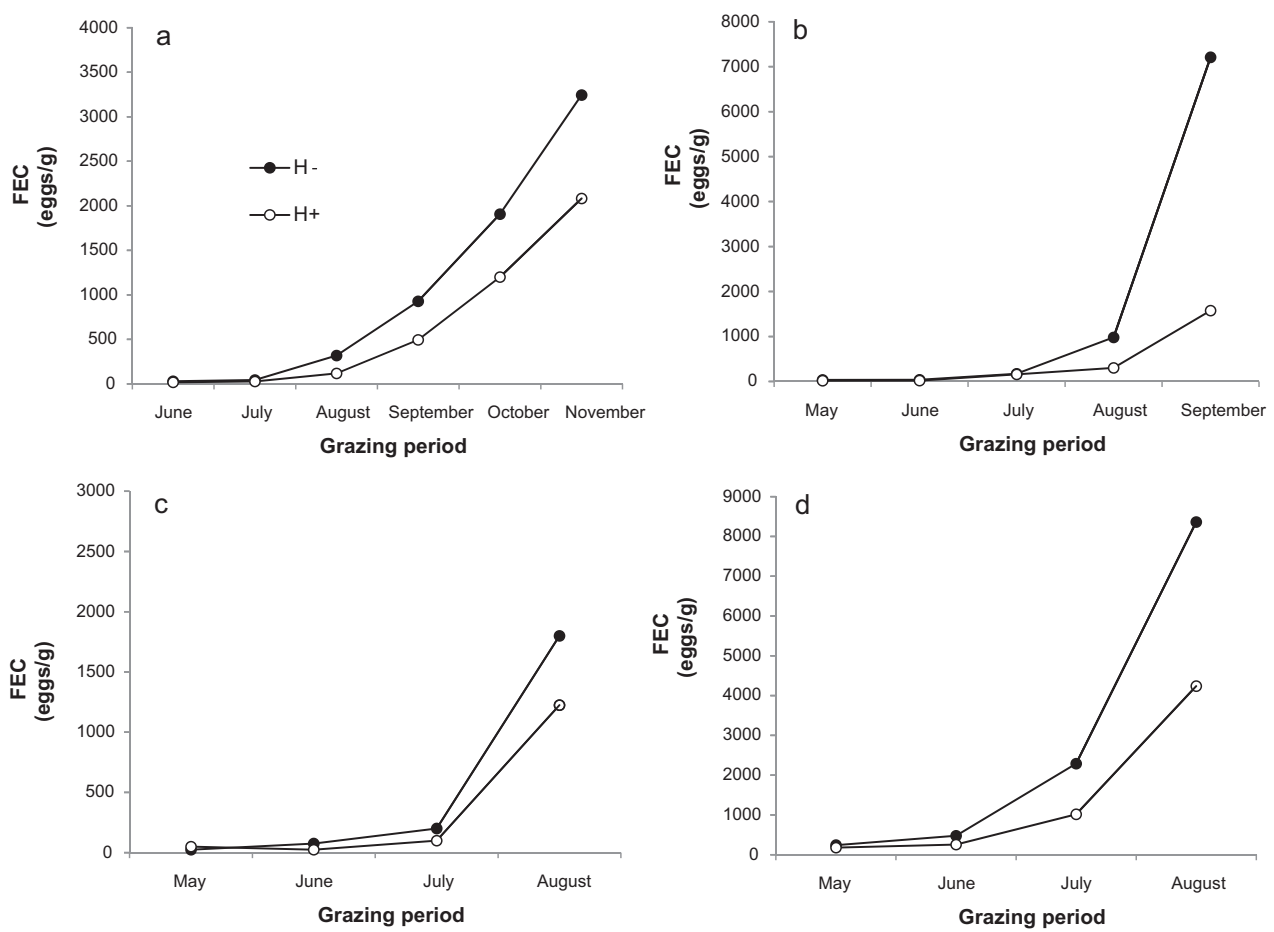

Fig. 1. Faecal gastrointestinal nematode egg counts (FEC) during the experimental grazing period in nonlactating (a and b) and lactating (c and d) goats grazing perennial rye-grass-white clover pastures, with or without heather supplementation $\left(\mathrm{H}^{+}\right.$, supplemented with freshly cut heather ad libitum every 3 days; $\mathrm{H}-$, nonsupplemented).

Data from (a) Osoro et al. (2007a); (b) Osoro et al. (2007c); (c) Frutos et al. (2008); and (d) Celaya et al. (2010).

goats naturally infected by GI nematodes as mentioned before (Hoste et al., 2005a; Madibela and Jansen, 2003; Min et al., 2004, 2005; Moore et al., 2008; Paolini et al., 2003b, 2005b; Pomroy and Adlington, 2006; Shaik et al., 2006; Terrill et al., 2007, 2009). A rise in FECs has also been observed in naturally infected goats grazing acacia (8 different genera) shrub woodland and given polyethylene glycol (PEG), a tannin-binding agent that inhibits the effects of tannins (Kabasa et al., 2000).

The lower FEC could be of double origin, either as a consequence of a reduction in the nematode burden or a lower fecundity of female worms. Cashmere goats grazing upland perennial ryegrass-white clover pastures at two stocking rates (38 vs. 24 goats/ha) and supplemented or not with heather were necropsied at the end of the season (Osoro et al., 2009). In goats managed under the high stocking rate, the mean of total $T$. circumcincta counts was significantly lower in supplemented animals, and it is also noteworthy that fecundity in utero and length of $T$. circumcincta females in supplemented goats were higher than those observed in non-supplemented animals. This probably indicates a long-term established nematode population, suggesting that heather could affect the development of the incoming third-stage $T$. circumcincta larvae. On the contrary, no differences were found in Trichostrongylus spp. counts, but fecundity and development of female nematodes tended to be lower than observed in control goats. Lower adult T. circumcincta and Trichostrongylus spp. counts were also observed in grazing Cashmere does and their single kids supplemented with heather (unpublished data). The fertility of female trichostrongyles in those does tended to be lower when compared to controls. In kids, the fertility of abomasum trichostrongyles was significantly lower than controls, but no differences for intestinal nematodes were found.

Previous studies reported a variable effect of tannins on parasitic nematode numbers naturally acquired after they have been established in goats. Under tropical conditions, a significant reduction in FECs (34\%) and nematode numbers was found in goats experimentally infected with $H$. contortus which received dried leaves of Acacia karoo, a tropical leguminous tree rich in CT (Kahiya et al., 2003). The consumption of Lysiloma latisiliquum, a common tree species of the tropical forest vegetation of Central America has leaves which contain high levels of CT, was also studied in goats infected with $H$. contortus and T. colubriformis, showing a reduction in the establishment of both species larvae (Brunet et al., 2008b). The effects of sainfoin hay have also been tested on existing GI nematode parasite populations (Hoste et al., 2005a; Paolini et al., 2003b, 2005a) and incoming larvae of $H$. contortus (Paolini et al., 2005b). Goats naturally infected with a mixed infection of $H$. contortus, $T$. circumcincta and $T$. colubriformis and fed sainfoin showed lower levels of nematode egg excretion and a decrease in worm fertility but no change in worm population. In addition, a higher consumption of hay and better host resilience were observed (Paolini et al., 2005a). Another study carried out in a dairy goat farm showed that dairy goats naturally infected by GI nematodes and fed sainfoin regularly show a significant reduction of egg 
output, without negative consequences on milk production when compared with goats fed no sainfoin (Hoste et al., 2005a). However, there was no effect from sainfoin on the establishment of $H$. contortus third-stage larvae in experimentally infected goats (Paolini et al., 2005b).

The effects of a commercial extract of quebracho (Schinopsis sp.) CT have been investigated in goats under controlled conditions. These studies compared the effects of CT either on an established population of adult worms (curative treatment) or on incoming third-stage larvae (preventive treatment). In goats previously infected with 10,000 third-stage larvae of $H$. contortus, a significant egg output reduction with a decrease in female fecundity was observed (Paolini et al., 2003a). However, no effects of quebracho CT were found on worms established in goats experimentally infected with 1500 larvae of $H$. contortus per day for three consecutive days (Paolini et al., 2005b). Similar experiments conducted to investigate the effects of quebracho CT in goats on adult populations of $T$. circumcincta and $T$. colubriformis, and the establishment of infective larvae of these two species showed a curative effect of CT on GI nematodes and a reduction by two-thirds of the worm populations recovered at necropsy; this effect being significant for the intestinal species and close to significant for the abomasal one (Paolini et al., 2003c).

Sericea lespedeza is a high-CT warm season perennial legume, and when consumed by goats, is associated with reduced FEC of GI nematodes (Min et al., 2004). Goats fed sericea lespedeza and infected with $H$. contortus showed a significant reduction in FEC and increased packed cell volume compared with controls fed perennial warm-season grass (predominantly bermudagrass: Cynodon dactylon) (Shaik et al., 2006). In addition, there was a direct effect on adult worms, with significantly lower numbers of both abomasal ( $H$. contortus and $T$. circumcincta) and intestinal ( $T$. colubriformis) nematodes when compared with control goats (Shaik et al., 2006). In southern US conditions, goats fed sericea lespedeza hay (50-70\% of the diet, Terrill et al., 2009) can effectively reduce nematode parasite infection levels through direct anthelmintic effects on the adult worms in the GI tract and by reducing parasite egg viability and/or larval development in faeces; and thus increase their performance (Moore et al., 2008; Shaik et al., 2006). Pelleting sericea lespedeza hay may enhance its efficacy against parasitic nematodes and facilitate the broader use of this forage in a small ruminant GI nematodes control program (Terrill et al., 2007).

In summary, CT could affect the establishment and consequently reduce the worm burden when acting on third stage-larvae. In contrast, they seem to mainly affect the worm reproductive function and the consequent contamination of pasture in animals harbouring adult worms. However, the mechanisms responsible for the effects of CT remain unclear. The reduction in FEC found in grazing goats cannot be attributed to the positive effect of extra protein availability for the animals supplemented with heather, because of the low protein content of heather (about 6.4\%). Nevertheless, the possibility of increasing intestinal protein availability in ruminants, e.g. through preventing dietary protein degradation in the rumen due to the CT effect (Mueller-Harvey, 2006; Waghorn, 2008), could indirectly affect parasitism level and performance. Assuming a lower protein supply of heather-containing diet compared to only-pasture diet, the FEC reduction observed in heather supplemented goats suggests a direct effect of heather consumption on parasite burden. In vivo studies (e.g. Brunet et al., 2008b) suggest a direct effect of CT on GI nematodes and in vitro experiments showed that CT interfere with the two steps of the larval establishment, exsheathment (Brunet et al., 2007) and the mucosal penetration (Brunet et al., 2008a). A delay in $H$. contortus larvae exsheathment was observed when CT-E. erigena extracts $(600 \mu \mathrm{g} / \mathrm{ml})$ were tested in vitro, but no effect was observed on T. colubriformis larvae (Bahuaud et al., 2006). However, it is not possible to discern between the effects of heather secondary compounds per se and potential diet composition effects on faecal output and eggs recovery.

Recently, trials with Cashmere goats experimentally infected with $T$. circumcincta and $T$. colubriformis have been conducted to investigate the preventive (on incoming third-stage larvae) and curative (on adult patent nematode population) effects of heather supplementation under controlled conditions (Ferre et al., 2009; Moreno-Gonzalo et al., 2009). In the curative experiment, a group of goats infected with T. colubriformis and supplemented with heather plus PEG was included (Frutos et al., in press). Initial results suggest that heather administration is associated with a reduction in the establishment of nematode larvae in the host, and a development and fecundity decrease of female parasite nematodes, but no reduction in worm numbers (Ferre et al., 2009; Moreno-Gonzalo et al., 2009).

\section{Effects of heather supplementation on host performance and nutrition}

In the grazing conditions described above, all adult Cashmere goats at pasture showed negative mean live weight changes for the whole experimental period, probably due to the limited availability of pasture (Merchant and Riach, 1994) and the increase in parasite burden (Coop and Kyriazakis, 2001) during the grazing season. Live weight decrease under low pasture availability conditions has been observed previously in goats grazing heather-gorse natural communities (Celaya et al., 2008). However, heather supplementation had a positive effect on live weight changes, and goats fed heather showed smaller losses of live body weight and body condition score than those with non-supplemented diets (Table 1). Furthermore, a positive correlation was observed between the percentage of heather in the diet and body weight changes during the grazing season (Osoro et al., 2007a, 2009). In contrast, as expected, the correlation coefficient between body weight changes and FEC was negative (Osoro et al., 2007c, 2009). The negative relationship between GI nematode infections and body weight changes has been observed in experimental and natural infections (Coop and Kyriazakis, 2001) and improved performance associated with the consumption of CT-rich plants, such as sericea lespedeza, was reported in Angora (Min et al., 2005) and Kiko $\times$ Spanish (Moore et al., 2008) goats naturally infected by GI nematodes. 
Two studies were also conducted to investigate the interaction of feeding tannin-containing heather with grazing management (Osoro et al., 2009), and with the supplementation with an energy feed (Celaya et al., 2010), respectively. In the first experiment, goats were managed at two stocking rates ( 24 and 38 goats/ha), and in the second, some groups of goats received oats (Avena sativa) supplementation consisting in $0.5 \mathrm{~kg}$ fresh matter per head per day. Although a significant effect of the stocking rate on GIN was observed, no differences in FEC were detected between goats supplemented with heather and those non-supplemented. A lower infectious pressure on FEC basis and subsequent nematode burden when compared to previous experiments, probably caused by an anomalous dry year could explain these results. However, supplemented goats under low stocking rate gained more live weight and a positive correlation was found between the percentage of heather in the diet and body weight changes. The combination of heather and oats significantly improved animal performance and reduced the FEC in supplemented animals. These results confirm the improved response to GI nematode infections when host nutrition is improved by supplementary feeding (Hoste et al., 2005b). Grazing kids supplemented with barley (Hordeum vulgare) and fed Duddingtonia flagrans spores showed reduced FEC and GI nematode burdens (Gómez-Rincón et al., 2007). In addition, Gutierrez-Segura et al. (2002) found improved resilience and resistance in browsing Criollo kids fed an energy supplement such as maize (Zea mays) compared with non-supplemented animals.

The work described was conducted under practical conditions (Table 1), trying to simulate extensive production systems of a less-favoured area where availability of forage may be limited during the summer and a number of goats not dewormed in mid-Autumn may die. The supplementation with heather reduced the goat mortality rate (Frutos et al., 2008; Osoro et al., 2007c). This is consistent with previous studies reporting the positive effect of CT consumption on the resilience of goats naturally infected by GI nematodes grazing shrub/woodlands (Kabasa et al., 2000) or feeding sainfoin (Paolini et al., 2005b) or sericea lespedeza (Min et al., 2005; Moore et al., 2008).

In another study performed in a heath-gorse shrubland with $24 \%$ of improved perennial rye-grass-white clover pasture and managing lactating suckler cows, ewes, and goats under mixed grazing, goats showed higher increases in FEC over the grazing season than cattle or sheep (Celaya et al., 2008). In part, this is probably due to a lower level of immunity developed in goats as they are natural browsers, compared with cattle or sheep which are mainly grazers (Hoste et al., 2008). Nevertheless, in this study the FECs found in goats, with maximum values of 200 epg at the end of the grazing season, were lower than those found in goats grazing on rye-grass-white clover pastures with no available heather, with a maximum of 8600 epg (Frutos et al., 2008; Osoro et al., 2007a,c), which suggests that integrating both vegetation types could enhance goat performance because of improved nutrition and health status.

Regarding the nutritional studies, although erroneous generalizations have persisted since the first reviews in the 1960 s and 1970 s which stated that tannins were harmful or toxic to mammals (Mueller-Harvey, 2006), our results have shown that the amount of tannins ingested by grazing goats supplemented with heather was insufficient to exert substantial anti-nutritional effects (Frutos et al., 2008; Osoro et al., 2007a,c). In fact, several authors have indicated that dietary concentrations of $50 \mathrm{~g} \mathrm{CT} / \mathrm{kg}$ DM are nutritionally beneficial (even though these recommendations originated mainly from feeding trials with Lotus species and cannot be directly applied to other feeds, Mueller-Harvey, 2006). The main benefit of tannins in ruminant nutrition stems from their negative effect on proteolysis and the initial consequence is a lower concentration of ammonia in the ruminal fluid, which was commonly observed in the heather supplemented animals. On the other hand, the volatile fatty acid concentrations were greater in these animals, which would point to an adaptation of rumen microorganisms to the consumption of CT-containing heather and a subsequently improved efficiency of ruminal fermentation (Table 1, Celaya et al., 2010; Frutos et al., 2008; Osoro et al., 2007c). The experimental infections using PEG showed the existence of some mild detrimental effects of heather tannins on diet digestibility, but they were not as negative as those observed previously using other CT-containing plant species (Frutos et al., in press). In vitro experiments involving batch cultures of rumen microorganisms, used to further investigate the nutritional effects of the inclusion of heather in the diet, confirmed the in vivo observations (Frutos et al., 2008, in press).

Anthelmintic effects (FEC reduction) were achieved with the dietary incorporation of estimated $20-32 \%$ heather containing up to $8.6 \%$ tannins, which may be considered as a low-to-moderate intake of tannins. Although the lowest dietary tannin threshold needed for anthelmintic effects remains unclear, results from the indoor experiments using PEG suggest that this is probably quite low and that the proportion of heather included in the diet to this end could be lowered (Frutos et al., in press). In addition, it is worth mentioning that the notion "lowto-moderate" tannin content could be misleading because, first, different bioactive plants contain tannins with different structures and hence reactivities, and second, different methods are used to analyse phenolic compounds and the equivalents in which the tannin content are expressed are not always given.

\section{Conclusions and perspectives}

It is concluded that (i) heather supplementation in grazing goats significantly reduce the level of GI nematode egg excretion, (ii) the faecal nematode egg count reduction could be associated with a decrease in worm fertility and/or reduction in the establishment of incoming thirdstage larvae, (iii) consumption of heather is associated with an apparent greater resilience of goats to GI nematode infections, and (iv) the amount of tannins consumed by goats offered heather does not seem to be associated with substantial anti-nutritional effects, which eventually resulted in a better performance of animals incorporating these shrubs in their diet.

In the near future, the characterization of bioactive compounds included in heather and in vitro studies to clarify 
their mechanism of action on different parasite stages (e.g. the possible interference on larval exsheathment or mucosal penetration, or both, to explain the reduction in the establishment of nematode larvae) will be carried out. Furthermore, trials including different herbivore species, such as goats, sheep, cattle, and horses, have been designed to investigate the effects of mixed grazing partially improved heathlands on GI nematodes infections and performance.

Practical application of this knowledge in temperate areas would support the management of plots integrating productively improved pastures with high nutritive value (rye-grass-white clover) with natural vegetation communities including tannin-containing plants, such as heather species. Improved pastures could be used to increase protein and energy intake and natural vegetation for fibre, minerals, and secondary compounds that contribute to achieve sustainable goat (and other herbivores) production systems with a lower dependence on conventional chemotherapy.

\section{Conflict of interest}

\section{None.}

\section{Acknowledgements}

We thank the staff at Carbayal research farm for their help in the field work. Rafael Celaya was partly funded by the European Social Fund and Javier Moreno-Gonzalo was financed by INIA. This work was supported by the Spanish National Institute for Agrarian and Food Research and Technology (INIA, Project RTA2007-00098) and was also part of the EU research collaboration COST FA0805. Thanks are also hereby given to David Bruhn for his editorial assistance.

\section{References}

Bahuaud, D., Martínez-Ortíz de Montellano, C., Chauveau, S., Prevot, F., Torres-Acosta, F., Fouraste, I., Hoste, H., 2006. Effects of four tanniferous plant extracts on the in vitro exsheatment of third-stage larvae of parasitic nematodes. Parasitology 132, 545-554.

Brunet, S., Aufrere, J., El Babili, F., Fouraste, I., Hoste, H., 2007. The kinetics of exsheathment of infective nematode larvae is disturbed in presence of tannin-rich plant (sainfoin) both in vitro and in vivo. Parasitology 134, 1253-1262.

Brunet, S., Jackson, F., Hoste, H., 2008a. Effects of sainfoin (Onobrychis viciifolia) extract and monomers of condensed tannins on the association of abomasal nematode larvae with fundic explants. Int. J. Parasitol. 38, 783-790.

Brunet, S., Martínez-Ortíz de Montellano, C., Torres-Acosta, J.F.J., SandovalCastro, C.A., Aguilar-Caballero, A.J., Capetillo-Leal, C., Hoste, H., 2008b. Effect of the consumption of Lysiloma latisiliquum on the larval establishment of gastrointestinal nematodes in goats. Vet. Parasitol. 157, 81-88.

Celaya, R., Oliván, M., Ferreira, L.M.M., Martínez, A., García, U., Osoro, K., 2007. Comparison of grazing behaviour, dietary overlap and performance in non-lactating domestic ruminants grazing on marginal heathland areas. Livest. Sci. 106, 271-281.

Celaya, R., Benavides, R., García, U., Ferreira, L.M.M., Ferre, I., Martínez, A., Ortega-Mora, L.M., Osoro, K., 2008. Grazing behaviour and performance of lactating suckler cows, ewes and goats on partially improved heathlands. Animal 2, 1818-1831.

Celaya, R., Ferreira, L.M.M., Moreno-Gonzalo, J., Frutos, P., Hervás, G., Ferre, I., García, U., Ortega-Mora, L.M., Osoro, K., 2010. Effects of heather and oat supplementation on gastrointestinal nematode infections and performance of grazing Cashmere goats. Small Rumin. Res. 91, 186-192.
Cheeke, P.R., Palo, R.T., 1995. Plant toxins and mammalian herbivores: co-evolutionary relationships and antinutritional effects. In: Journet, M., Grenet, E., Farce, M.H., Thériez, M., Demarquilly, C. (Eds.), Recent Developments in the Nutrition of Herbivores. Proceedings of the IVth International Symposium on the Nutrition of Herbivores. INRA Editions, Paris, France, pp. 437-456.

Coop, R.L., Kyriazakis, I., 2001. Influence of host nutrition on the development and consequences of nematode parasitism in ruminants. Trends Parasitol. 17, 325-330.

Ferre, I., Moreno-Gonzalo, J., García, U., Frutos, P., Celaya, R., Ferreira, L.M.M., Ortega-Mora, L.M., Osoro, K., 2009. Anthelmintic effect of heather supplementation on gastrointestinal nematodes in goats. In: Proceedings of the COST Action FA0805 Goat-Parasite Interactions: From Knowledge to Control (CAPARA), 1st Working Groups Workshop \& Management Committee Meeting, Thessaloniki, Greece.

Frutos, P., Hervás, G., Ramos, G., Giráldez, F.J., Mantecón, A.R., 2002. Condensed tannin content of several shrub species from a mountain area in northern Spain and its relationship to various indicators of nutritive value. Anim. Feed Sci. Technol. 95, 215-226.

Frutos, P., Moreno-Gonzalo, J., Hervás, G., García, U., Ferreira, L.M.M., Celaya, R., Toral, P.G., Ortega-Mora, L.M., Ferre, I., Osoro, K., 2008. Is the anthelmintic effect of heather supplementation to grazing goats always accompanied by anti-nutritional effects? Animal 2, 1449-1456.

Frutos, P., Hervás, G., Celaya, R., Moreno-Gonzalo, J., Rodríguez, A.B., García, U., Ferre, I., Ortega-Mora, L.M., Osoro, K. Effect of the use of heather as an anthelmintic in goats infected with Trichostrongylus colubriformis on ruminal fermentation and digestibility. Options Méditerranéennes, in press.

Gómez-Rincón, C., Uriarte, J., Valderrábano, J., 2007. Effect of nematophagous fungus Duddingtonia flagrans and energy supplementation on the epidemiology of naturally infected kids. Vet. Res. 38, 141-150.

Gutierrez-Segura, I., Torres-Acosta, J.F., Aguilar-Caballero, A., CanulKu, I., Lozano-Argaez, I., Cob-Galera, L., 2002. Improving resilience and resistance against nematode infections through maize supplementation in Criollo kids. In: Responding to the Increasing Global Demand for Animal Products, BSAS-ASAS, Mérida, Yucatán, México, pp. 78-79.

Hoste, H., Gaillard, L., Le Frileux, Y., 2005a. Consequences of the regular distribution of sainfoin hay on gastrointestinal parasitism with nematodes and milk production in dairy goats. Vet. Parasitol. 59, 265-271.

Hoste, H., Torres-Acosta, J.F., Paolini, V., Aguilar-Caballero, A., Etter, E., Lefrileux, Y., Chartier, C., Broqua, C., 2005b. Interactions between nutrition and gastrointestinal infections with parasitic nematodes in goats. Small Rumin. Res. 60, 141-151.

Hoste, H., Jackson, F., Athanasiadou, S., Thamsborg, S.M., Hoskin, S.O., 2006. The effects of tannin-rich plants on parasitic nematodes in ruminants. Trends Parasitol. 22, 253-261.

Hoste, H., Torres-Acosta, J.F.J., Aguilar-Caballero, A.J., 2008. Nutrition-parasite interactions in goats: is immunoregulation involved in the control of gastrointestinal nematodes? Parasite Immunol. 30, 79-88.

Kabasa, J.D., Opuda-Asibo, J., ter Meulen, U., 2000. The effect of oral administration of polyethylene glycol on faecal helminth egg counts in pregnant goats grazed on browse containing condensed tannins. Trop. Anim. Health Prod. 32, 73-86.

Kahiya, C., Mukaratirwa, S., Thamsborg, S.M., 2003. Effects of Acacia nilotica and Acacia karoo diets on Haemonchus contortus infection in goats. Vet. Parasitol. 115, 265-274.

Kaplan, R.M., 2004. Drug resistance in nematodes of veterinary importance: a status report. Trends Parasitol. 20, 477-481.

Ketzis, J.K., Vercruysse, J., Stromberg, B.E., Larsen, M., Athanasiadou, S. Houdijk, J.G.M., 2006. Evaluation of efficacy expectations for novel and non-chemical helminth control strategies in ruminants. Vet. Parasitol. 139, 321-335.

Madibela, O.R., Jansen, K., 2003. The use of indigenous parasitic plant (Viscum verrocosum) in reducing faecal egg counts in female Tswana goats. Lives. Res. Rural Dev. 15, 1-6.

Makkar, H.P., 2003. Quantification of Tannins in Tree and Shrub Foliage a Laboratory Manual. Kluwer Academic Publishers, Dordrecht, The Netherlands.

Merchant, M., Riach, D.J., 1994. The intake and performance of Cashmere goats grazing sown swards. Grass Forage Sci. 49, 429-437.

Min, B.R., Pomroy, W.E., Hart, S.P., Saúl, T., 2004. The effect of short-term consumption of a forage containing condensed tannins on gastrointestinal nematode parasite infections in grazing weather goats. Small Rumin. Res. 51, 279-283. 
Min, B.R., Hart, S.P., Millar, D., Tomita, G.M., Loetz, E., Saúl, T., 2005. The effect of grazing forage containing condensed tannins on gastrointestinal parasite infection and milk composition in Angora does. Vet. Parasitol. 130, 105-113.

Moore, D.A., Terrill, T.H., Kouakou, B., Shaik, S.A., Mosjidis, J.A., Miller, J.E., Vanguru, M., Kannan, G., Burke, J.M., 2008. The effects of feeding sericea lespedeza hay on growth rate of goats naturally infected with gastrointestinal nematodes. J. Anim. Sci. 86, 2328-2337.

Moreno-Gonzalo, J., Osoro, K., García, U., Frutos, P., Celaya, R., Ferreira, L.M.M., Ortega-Mora, L.M., Ferre, I., 2009. Effect of heather consumption on incoming larvae and established population of Trichostrongylus colubriformis in experimentally-infected Cashmere goats. In: Proceedings of the 22nd International Conference of the World Association for the Advancement of Veterinary Parasitology, Calgary, Canada.

Mueller-Harvey, I., 2006. Unravelling the conundrum of tannins in animal nutrition and health. J. Sci. Food Agric. 86, 2010-2037.

Osoro, K., Benito-Peña, A., Frutos, P., García, U., Ortega-Mora, L.M., Celaya, R., Ferre, I., 2007a. The effect of heather supplementation on gastrointestinal nematode infections and performance in Cashmere and local Celtiberic goats on pasture. Small Rumin. Res. 67, 184-191.

Osoro, K., García, U., Jáuregi, B.M., Ferreira, L.M.M., Rook, A.J., Celaya, R., $2007 \mathrm{~b}$. Diet selection and live-weight changes of two breeds of goats grazing on heathlands. Animal 1, 449-457.

Osoro, K., Mateos-Sanz, A., Frutos, P., García, U., Ortega-Mora, L.M., Ferreira, L.M.M., Celaya, R., Ferre, I., 2007c. Anthelmintic and nutritional effects of heather supplementation on Cashmere goats grazing perennial ryegrass-white clover pastures. J. Anim. Sci. 85, 861-870.

Osoro, K., Celaya, R., Moreno-Gonzalo, J., Ferreira, L.M.M., García, U., Frutos, P., Ortega-Mora, L.M., Ferre, I., 2009. Effects of stocking rate and heather supplementation on gastrointestinal nematode infections and host performance in naturally-infected Cashmere goats. Rangeland Ecol. Manage. 62, 127-135.

Paolini, V., Bergeaud, J.P., Grisez, C., Prevot, F., Dorchies, Ph., Hoste, H., 2003a. Effects of condensed tannins on goats experimentally infected with Haemonchus contortus. Vet. Parasitol. 113, 253-261.
Paolini, V., Dorchies, Ph., Hoste, H., 2003b. Effects of sainfoin hay on gastrointestinal nematode infections in goats. Vet. Rec. 152, 600-601.

Paolini, V., Frayssines, A., De La Farge, F., Dorchies, Ph., Hoste, H., 2003c. Effects of condensed tannins on established populations and on incoming larvae of Trichostrongylus colubriformis and Teladorsagia circumcincta in goats. Vet. Res. 34, 331-339.

Paolini, V., De La Farge, F., Prevot, F., Dorchies, Ph., Hoste, H., 2005a. Effects of the repeated distribution of sainfoin hay on the resistance and the resilience of goats naturally infected with gastrointestinal nematodes. Vet. Parasitol. 127, 277-283.

Paolini, V., Prevot, F., Dorchies, Ph., Hoste, H., 2005b. Lack of effects of quebracho and sainfoin hay on incoming third-stage larvae of Haemonchus contortus in goats. Vet. J. 170, 260-263.

Pomroy, W.E., Adlington, B.A., 2006. Efficacy of short term feeding of sulla (Hedysarum coronarium) to young goats against a mixed burden of gastrointestinal nematodes. Vet. Parasitol. 136, 363-366.

Shaik, S.A., Terrill, T.H., Millar, J.E., Kouakou, B., Kankan, G., Kaplan, R.M., Burke, J.M., Mosjidis, J.A., 2006. Sericea lespedeza hay as a natural deworming agent against gastrointestinal nematode infections in goats. Vet. Parasitol. 139, 150-157.

Stear, M.J., Doligaska, M., Donskow-Schmelter, K., 2007. Alternatives to anthelmintics for the control of nematodes in livestock. Parasitology 134, 139-151.

Terrill, T.H., Mosjidis, J.A., Moore, D.A., Shaik, S.A., Millar, J.E., Burke, J.M., Muir, J.P., Wolfe, R., 2007. Effect of pelleting on efficacy of sericea lespedeza hay as a natural dewormer in goats. Vet. Parasitol. 146, 117-122.

Terrill, T.H., Dykes, G.S., Shaik, S.A., Miller, J.E., Kouakou, B., Kannan, G., Burke, J.M., Mosjidis, J.A., 2009. Efficacy of sericea lespedeza hay as a natural dewormer in goats: dose titration study. Vet. Parasitol. 163 , 52-56.

Waghorn, G., 2008. Beneficial and detrimental effects of dietary condensed tannins for sustainable sheep and goat production - progress and challenges. Anim. Feed Sci. Technol. 147, 116-139.

Waller, P.J., Thamsborg, S.M., 2004. Nematode control in green ruminant production systems. Trends Parasitol. 20, 493-497. 